\title{
Between Ramaphosa's New Dawn and Zuma's Long Shadow: Will the Centre hold?
}

\section{Ashwin Desai}

\section{Abstract}

Cyril Ramaphosa was sworn in as South Africa's President in February 2018 after the late-night resignation of Jacob Zuma. His ascendency came in the wake of a bruising battle with Nkosazana Dlamini-Zuma that saw him become head of the African National Congress (ANC) by the narrowest of margins. Ramaphosa promised a new dawn that would sweep aside the allegations of the looting of state resources under the Zuma Presidency and restore faith in the criminal justice system. This article firstly looks at the impact that the Zuma presidency has had on South African politics against the backdrop of the Nelson Mandela and Thabo Mbeki years. The article then focuses on Ramaphosa's coming to power and what this holds for pushing back corruption and addressing the seemingly intractable economic challenges. In this context, I use Gramsci's ideas of the war of manoeuvre and war of position to provide an understanding of the limits and possibilities of the Ramaphosa presidency. The analysis presented is a conjunctural analysis that as Gramsci points out focusses on 'political criticism of a day-to-day character, which has as its subject top political leaders and personalities with direct governmental responsibilities' as opposed to organic developments that lend itself to an understanding of durable dilemmas and 'give rise to socio-historical criticism, whose subject is wider social groupings - beyond the public figures and beyond the top leaders' (quoted in Morton 1997: 181).

Keywords: Zuma, Ramaphosa, Black Economic Empowerment, State Capture 


\section{Introduction}

I was in the crowd in 1994 as the Oryx beat by, the bright flag of a new South Africa fluttering beneath. Seeing these helicopters, still in their bush war camouflage, dipping in salute to newly crowned president, Nelson Mandela, sent a lump to my throat. This was a surprising reversal of sentiment by my windpipe. After all, until that very day, it had railed against compromises with the apartheid government that brought this exact moment to pass. It was a time in which ideology and a trachea's strident treatise of bourgeois traps was no match for sheer spectacle and songs of redemption. People mingled, smilingly. Sworn enemies were reconciled, dreaming up a common future on greener lawns. Those who found it hard to admit the humanity of Black people now saluted them. Implied regret, if not apology hung in the air. South Africans had been entrusted with decisions. The state was now at the command of a democratic government. It would be a long road, with realpolitik pitting the way, but those in charge could finally address the needs of a large and excluded black underclass. There was reason to believe they would make a go of it. The first African National Congress (ANC) cabinet brimmed with people of substance (Lodge 2003). Most revered were the stoic grandfathers, emerging without an iota of bitterness from that rocky isle off the Cape where they'd been locked up for a quarter of a century. The optics were almost biblical.

Nelson Mandela was chief among these elders. For the first years of ANC rule, his presidency more or less maintained the positive mood. In the desperate and neglected townships, black people still suffered in throngs. But the promise that government would make rational, good faith decisions to make their life better was a credible one (Waldmeir 1997). The ANC slogan, 'A Better Life for All' soon sprouted material, if modest effects. Pensions were extended to all races, water was piped to areas up until then reliant on streams, and numerous houses were built. Under an ambitious, although hollowed out reconstruction and development programme (RDP), bulldozers were set to work, this time digging foundations instead of knocking down walls.

These stellar moves however did not dent the underlying structure of an economy whose commanding heights still lay overwhelmingly in white hands (Ashman et al. 2017). Disquiet was raised about the genuflection to a prevailing macro-economic orthodoxy that seemed to burden the poor and privilege the rich, exemplified by the accelerated reduction of tariffs on clothing and textile imports that with a stroke of a pen destroyed thousands of 
working-class lives, denuding the manufacturing sector and increasing reliance on financial capital and primary-commodity exports (Desai 2002; Marais 2011).

Still, what Mandela gave us was an 'RDP of the Soul' (the subject of his last speech to parliament); the possibility of building something beautiful and exceptional out of apartheid's ruins.

With the coming to power of Thabo Mbeki, the feeling was that a greater commitment would be made towards a transformative agenda, notwithstanding his own support for macro-economic orthodoxy and penchant for political centralisation and control from the top (Jacobs 1999). The argument went that the stability created during the Mandela years would serve as a launch pad for more aggressive challenges to be made on the ownership and control of the economy.

\section{Thabo Mbeki: The Dress Rehearsal?}

Mbeki spoke to the hopes of most black people that, with much of the symbolic edifice of segregation dismantled under Mandela, substantive changes in their economic prospects would naturally follow. Mbeki took some steps in this direction, especially in trying to open economic spaces for a Black middleclass to develop. He put constant pressure on white-dominated sectors of the economy to take black equity partners and diversify their management. State procurement codes throughout the entire supply chain gave preferential treatment to businesses with majority black ownership. The civil service expanded, drawing in and facilitating the development of black managers, professionals and leaders. Mbeki also coined the term African Renaissance, which represented his attempt to co-ordinate a continent-wide emergence (some would say re-emergence) of African excellence in the economic, cultural and diplomatic spheres (Gevisser 2007).

While global economic forces hemmed in Mbeki and his court, the strictures of prevailing economic orthodoxy had stitched up the once Marxist ideologues. One of the ironies of Mbeki is that while he was quick to take offence at the way Africa was generally regarded in the North, he was slavish in kowtowing to their economic tutoring. Despite this, the ANC government still tied to and dependent on the South African Communist Party (SACP) and Congress of South African Trade Unions (Cosatu) for electoral support, struck too many false chords with elusive investors (Marais 2011; Bundy 2014). 
What will mark Mbeki's presidency is his disastrous HIV/AIDS denialism which flowed from these hang-ups. For Mbeki embraced crackpot views on HIV/AIDS, the effects of which denied hundreds of thousands of people life-saving medicines. They died. His denialism stemmed in equal measure from an intellectual arrogance in purporting to understand concepts beyond his expertise and a frustration that HIV/AIDS pandemic statistics seemingly confirmed negative stereotypes of Africans as dirty, disease-prone and promiscuous (Mbali 2013).

However, in the aftermath of Zuma's presidency, history might proffer another indictment. This is that Mbeki's centralisation of power and manipulation of state institutions, especially law enforcement, were but a dress rehearsal for Zuma's own excesses. Indeed, were it not for Mbeki's own chief prosecutor, Bulelani Ngcuka's meddling attempts to arrange a politically opportune moment to charge Zuma ahead of the ANC's Polokwane elective congress, Zuma would have been indicted on corruption charges in 2009 already. These charges related to a 'generally corrupt' relationship with business-fixer Schabir Shaik, for which the latter had already been convicted and imprisoned (Basson 2012). But Mbeki and Zuma were intense rivals for leadership of the ANC at the time the criminal investigation into Zuma ripened. And, when tape-recordings of telephone conversations about manipulating the judicial process against his former deputy found themselves into the hands of Zuma's legal team, an embarrassed prosecuting authority backed off. Despite the strength of the allegations, the National Prosecuting Authority (NPA) deemed the process too tainted to proceed (Basson \& du Toit 2017). Make no mistake, this was a politically convenient decision too, for by the time it was made, Zuma had deposed Mbeki at the ANC elective congress, and in the ordinary course of events, the popular politician stood to be installed as president of the country. The NPA's decision to give Zuma a free pass was, eight years later, found by the Supreme Court of Appeal to have been wrong. But the horse had bolted, pulling a cart of scoundrels through the land. Historians will undoubtedly lay some of the blame at Mbeki's door. Without such a handy expedient to avoid charging the incoming ANC president, Zuma would have been disqualified and the country arguably saved a decade of looting. Without the useful precedent set by Mbeki of how to stock key law enforcement positions with hacks, Zuma may have been better impeded when he did the same (Gumede 2007). 


\section{'A Simple Man' Cometh (Ronnie Kasrils)}

Thus, it came to pass that ten years after Mandela stepped down as South Africa's president, Jacob Gedleyihlekisa Zuma occupied his chair in the Union Buildings. Zuma rose through the ranks of the same party as Nelson Mandela. Both were incarcerated on Robben Island. When the ANC took power in South Africa, they sat together in the highest echelons of decision-making. In 2005, when Jacob Zuma needed cash, a seemingly permanent condition, he hit Mandela up for two million rand (Johnson 2010: 530). Mandela even wore pictures of 'Zuma for President' ahead of the 2009 elections. So it is that as South Africans, we have had to face a brutal fact: the historical impetus and political force that gave us our greatest statesman, in short order thereafter, apparently gave us our biggest crook (Calland 2013).

The crookedness was not as obvious in Zuma's first months in office. Zuma made excellent use of the persecution by his predecessor Mbeki to solidify support. He also cultivated an image of being marginalised, helped by his obvious lack of formal education, enthusiastic polygamy, ruralitarian wit and easy-going personality. For some, he embodied the unapologetic return of authentic African values to South African politics, contra to the Westernised ethos of ANC leaders who came before. As time went by, he showed that he was even more adept at deploying loyalists in key state institutions than his predecessor. Where Mbeki had tinkered with the heads of justice and police, Zuma dived right in, selecting deputies and unit commanders, such as Berning Ntlemeza, who headed the police unit charged with investigating (or not) serious crimes such as corruption. The depth of Zuma's reach into state institutions was impressive. According to evidence emerging at the Zondo Commission into State Capture, he pushed ministers to approve ruinous nuclear deals, buy aircraft at exorbitant prices and off-load critical defense intellectual property in business deals solely benefiting his benefactors. Beyond the mega-deals in Zuma's wake, office-bearers the length and breadth of the ANC considered it their due and time to 'eat'. Under Zuma, the ANC's conquest of state and parastatal procurement departments was an unending feeding trough.

This did not mean that they always made unjustifiable decisions. Some refused to toe the line completely. But those civil servants consistently and naively insisting on observance of the Public Finance Management Act were either rudely treated or viciously swept aside; it was their choice which way 
they swung. Under Zuma, a whole strata of officials deemed obstructive to corruption were purged, most notably straight-arrow tax investigators, police and prosecutors. Careers were cut short and the lives of honest people ruined in smears and drawn-out disciplinary processes on the weakest of evidence.

The only thing regulating the extent of corruption were a sniffer-dog press, combative civil society that drew in opposition parties and an unimpressed judiciary. To be re-elected, the ANC would have to at least deliver on some projects benefiting the poor or keep what was already working ticking over. They had to avoid scandals and jail sentences. And so, the odd situation developed where a great deal of work and money was put into simulating compliance and getting someone else to do the work, with a substantial cut going to those who landed the deals. This required bought auditors, teams of smooth-talking lawyers, clever fronting and dollops of inventive lying. For example, in passing off a swimming pool built at Zuma's rural palace at taxpayers' expense, Zuma and his supporters bald-facedly insisted that it was nothing more than a reservoir from which firefighters could draw water in case of emergency. It was both shocking and amusing to see how many ANC politicians earnestly lined up behind corruption-enabling canards like these (Public Protector 2016).

Half-way through his term, Zuma began to jettison many of the niceties expected of an ANC statesman. The veneer of legality was too tedious to maintain. The pressure on his supporters to make a quick buck before Zuma left office increased. The looting was no longer spread so widely. His cronies monopolised state tenders as Zuma and his circle blatantly feathered their nests, or to use the African idiom, ate (Basson \& du Toit 2017). Thanks to the doggedness of opposition parties, NGOs and the press, the 783 old corruption charges that Zuma had carefully dodged were revived in the courts in 2017. Credible allegations of new wrong-doing mounted. At this point, Zuma's political style changed from genial to ruthless jobbery.

Zuma's (nearly) two terms in office were characterised by a wholesale looting of state coffers by persons connected to him and his family. While most of the allegations of corruption implicating Zuma involved the Indian expatriate Gupta family, his example was apparently followed by a range of cabinet ministers, provincial premiers, mayors and senior civil servants. The coffers of electricity (Eskom) and rail (Transnet) parastatals were raided to pay fantastic amounts by means of patently illegal contracts for feeble consultancy advice. Giving lie to the argument of threatening white monopoly capital 
(WMC) and challenging Western imperial interests, US based companies like McKinsey and Co and German software firm SAP became embroiled in these schemes (Bhorat et al. 2017).

Many South Africans were familiar with the unfolding narrative at the Zondo Commission, whose first months involved revelations of the schemes of the Gupta/Zuma axis, often referred to as the Zuptas. But into January 2019, a fresh set of allegations involving a white 'struggle' family, the four Watson brothers from Port Elizabeth, exploded onto our television screens. They owned a company called Bosasa that appeared to be engaged in a systematic bribery of state officials and MPs which enabled them to access a series of state contracts. The man leading the evidence was a high-level insider of this criminal enterprise, ironically scoring multi-billion contracts from Correctional Services which locked up the country's criminals.

The extent of the allegations led to the question of whether the very terms of a negotiated settlement has given rise to systemic corruption, embedding it as a 'normal' part of governance in South Africa.

One of the central reasons for this argument, it is held, lies in the way in which the ANC sought to build a Black patriotic bourgeoise. This involved white dominated conglomerates handing out shares to a Black politically connected elite: what Chris Malikane, an economist at Wits University, provocatively calls 'bribes' (2017). While not in law illegal, the way it was done and to whom shares and other largesse were handed had all the trappings of corrupt practice. While this was portrayed under the Mbeki presidency as a trojan horse in the making that would de-racialise the economy, white conglomerates saw these newly minted Black billionaires as the front-line in defence of an existing system of capital accumulation. Chair of AngloAmerican Platinum and president of the Chamber of Mines in 2002, Barry Davison, put it this way: 'More people in this country have to feel they are part of the system, that they are benefiting from the system, that the system is working with them, for them, and not excluding them. I don't think there's any doubt that government and industry are in total agreement on this issue' (quoted in MacDonald 2004: 647).

As this policy unfolded, white conglomerates had to enter into partnership with local black-owned firms in order to obtain state tenders. Under Zuma, those black-owned firms were often nothing more than rent-seeking fronts for the president and his friends. By stacking the Boards and top management of state agencies with feeble-minded or corrupt individuals, with 
those at the helm of this scheme often succeeding in combining both qualities in one appointment, work was steered the way of those who were politically connected.

It is something that may as well be said. Black Economic Empowerment (BEE) has skirted so close to what actually defines corruption for so long that cronyism is almost accepted as a routine feature of state procurement (Saul \& Bond 2014). This is because big business either routinely seeks, or is required, to partner with PEPs (politically-exposed persons). They are the main beneficiaries of lucrative assignments of shares or joint ventures that are supposed to drive economic transformation by transferring skills and providing experience to smaller black-owned entities. That is the theory and fortunately there are some examples of where it has worked. For the most part however, the local business partner is selected on the basis of the political influence they can provide (Russell 2011). Indeed, as much as President Ramaphosa is cast as the antithesis of corruption, he himself owes his fantastic wealth to highly favourable BEE cuts in businesses given to him in the mid1990s. As personable as he is, nothing other than his ability to influence ANC cadres on policy questions recommended the former mining union boss to the boardroom. It may be argued that influence-mongering on general questions of policy differs only in degree from influence mongering to win particular tenders from the state. The former is about stasis and protecting property and opportunities already in place. The latter is about transformation and acquiring new wealth and opportunity. Wealth is the common denominator and is acquired, it appears, by hook or crook.

Coming into the presidency with 783 unadjudicated corruption charges, Jacob Zuma was, to put it mildly, a deeply compromised man. As Zuma's power increased, his funders went from merely unsavoury to positively rotten. We're talking arms dealers, gangsters, tobacco smugglers and businessmen like the Gupta family newly arrived from India, a brotherly trio so gauchely corrupt that other thieves shunned them in disgust (Pauw 2017).

The president's failings, although tedious in the unmasking are, thanks to an independent press and judiciary, now notorious. As a consequence of these exposés and the ongoing work of the Zondo Commission, we can confidently accuse several high-ranking police officers, taxmen, prosecutors, lawyers, and politicians of the highest crime: keeping treason in office for so long. The keepers cannot slink away into other pursuits as easily as they hoped.

It would be a mistake though to count the cost of the Zuma years by 
institutional wreckage alone. Institutions can be repaired, or at least the damage arrested. The enduring effects of Zuma's malfeasant rule rests in the incendiary discourses which an under-fire president unleashed on the body-politic. Under Zuma, racial stigmatisation of minorities became de rigueur. Black voices raised against state capture were silenced through wild allegations of working for the CIA or, bizarrely, trying to be a 'clever black' in the thrall of whites. Zuma, and those further down the rent-seeking supply chain, picked bitter fights with the business community, with the few civil servants who thwarted them, with the judiciary, oversight bodies, public intellectuals and NGOs. The purpose? To ward off the unmasking of state capture. For Zuma and his sudden coterie of racial nationalists were quite happy to outsource work to whites and Indians as long as they got a cut of the profits. They were more than happy to seek refuge with white advocates and to allegedly connive with white swindlers who moved their money off-shore. And, as revelations at the Zondo Commission have revealed, they were more than happy to take hand-outs from the 'white' Watson brothers. The fact that their nativism was filled with contradictory impulses does not mean that it differs from the standard fare served up in other places. They cloaked their bid for power in promises of instantaneous economic redemption (nationalisation, expropriation of property from whites, and free services and entitlements such as tertiary education). Nativists also need an enemy standing in the way of these redemptive measures. In South Africa, this was not hard to construe (Chipkin 2016).

\section{To the Left, to the Left}

To avoid prison and extend his rule via a hand-selected proxy in the persona of his former wife, Dr. Nkosazana Dlamini-Zuma, in 2016 and 2017, Zuma lurched suddenly towards the populist left. But my argument here differs from some on offer, although acknowledging similar facts. I do not protest that towards the end of Zuma's term of office, he sponsored or embraced redistributive slogans. My first argument is that he defamed arguments that actually needed a proper hearing. The second is that he advanced these arguments in a manner that has dangerously polluted the political atmosphere. The viability of these arguments does not matter to those who echo them any longer. They have become a battle-cry, standing in for treacherously provocative attitudes, still taboo in public discourse but hungry for a platform (Southall 2017). 
Before looking at the ideas Zuma has bequeathed in greater detail, let us first examine their genesis. With several court or chapter nine rulings threatening Zuma's interests in 2017 and with the malignant role of the Gupta family in state affairs under intense scrutiny, particularly after \#GuptaLeaks, Duduzane Zuma and the Guptas hired a well-known London PR company, Bell Pottinger to improve their image. This was to be done primarily by delegitimising their critics. Exploiting both enduring inequalities in the South African economy as well as the fact that the economy had faltered under Zuma mismanagement, the now notorious UK PR firm defined a suitable bogey-man (Thamm 2017). Far from Zuma being a kleptocrat, he was in fact a noble nationalist unfairly targeted by an entity called White Monopoly Capital (WMC). The concept of white monopoly capital denounced those supposedly harbouring Zuma's abundant detractors. So pervasive had criticism and exposure of Zuma's wrong-doing become in 2016 and 2017 that his persecutors had to be both ubiquitous and exceptionally resourceful if the allegations against him were all to be false. In column inches, pamphlets, speeches and twitter wars, Bell Pottinger proposed the Illuminati-like \#WMC as the nemesis of progressive blacks. \#WMC advanced its exploitative, imperialist and racist objectives through all people, black or white, who spoke of state capture. According to Zuma, state capture was an entirely false narrative. It did not exist. To borrow a term from across the Atlantic, it was fake news and he was an honest man. When the Public Protector found that Zuma should pay for several expensive features at his Nkandla palace, she was labelled an agent of \#WMC. When South Africa's premier investigative reporting hub, amaBhungane reported on leaked emails showing the pervasive influence of the Guptas on key Zuma family members, they were deemed bought by \#WMC. Even ANC critics of Zuma, Ramaphosa included, were daubed with this broad brush (Khumalo 2016).

\#WMC is a particularly elastic term. It tends to be applied, in popular parlance, to a class of people as diverse as real monopolies, such as De Beers and the television pay channel MultiChoice, pentopolies such as the five largest banks, through to mines and manufacturing enterprises, stretching to any successful medium or large business. The common thread is that suspicion of political wrong-doing rightly attaches to any enterprise's actions and indeed their very existence, on account of being run or owned by white people. At the very least, it crowds out 'indigenous' business people. The concept \#WMC, if not introducing, certainly gave respectability to sentiments openly and broadly 
hostile towards the white minority. This quickly extended to other minority groups in South Africa and soon it was open-season to question whether nonAfrican population groups in South Africa truly belonged, something unthinkable in mainstream political discourse since the dawn of democracy. Indeed, it became fashionable to suggest that Mandela himself was some kind of sell-out for having emphasised reconciliation (Areff 2015). All the time, the enemy was defined as WMC with their imperialist allies, while 'the people' were re-defined as 'indigenous' Africans.

In Zuma's last term, those associated with the president - his family, supporters and keepers - traded in constant racial jibes and baiting. Zuma condoned this low-intensity bigotry and chauvinism at the highest levels of the ANC, his cabinet in particular. So much so that the Thabo Mbeki Foundation spoke out against an ANC that was becoming infused with a 'narrow, racialistic, and chauvinistic nationalism' totally at odds with the ANC's founding principles (Mbeki 2018).

It is unlikely that Zuma's motives for resorting to populism are rooted in a sense that the poor would benefit from the policies he evinces or the barbs he throws. Zuma's facilitation of looting shows a callous disregard for the poor. Since the days of Themistocles, populism has been an electoral strategy by which aspirant elitists pit themselves against the establishment in the name of 'the people' (Laclau 2005). The intention is to achieve the spoils of power. In Zuma's case, his populism was a response to looming ostracism. Zuma needed a constituency to install Nkosazana Dlamini-Zuma as president of South Africa after him to ward this off and to continue the scheme described above. This constituency needed to be broader than just those benefitting from his largesse. The same applies to the use of \#WMC. With his failures exposed and his alleged crimes resurfacing, Zuma needed to constitute an elite to blame for his woes (Malala 2015).

Like so many beleaguered presidents, Zuma's resort to populism was politically rewarding. It provided an effective shield against evidence and a club with which to clobber those providing it. His son's PR company Bell Pottinger came up with one hashtag. For the other, \#Expropriation Without Compensation or \#EWC, he helped himself to the eggs that the EFF had so patiently brooded over in their own attempt at electoral success in 2019: free tertiary education and expropriation of white-owned land without compensation. By swiftly making these ANC policies, Zuma bequeathed his successor a political discourse that was radical, contentious, polarising and intolerant. 
Before he entered the land debate or attacked white business, Zuma stood exposed as senior member of a corrupt faction of politicians and billionaires. Subsequently, Zuma cast himself as a victim of historical plots. Both the acme and nadir of this was his insinuation that imperialist forces working with enemies within had poisoned him for an anti-imperialist stance in favour of the new economic bloc of Brazil, Russia, India, China, and South Africa, known as BRICS (McKenzie 2017). According to newspaper articles and the strenuous denials of a wife, the actual source of his discomfit was allegedly a disgruntled spouse at a lonely cooking pot (McKenzie 2017).

The contradictions of the Zumaites were palpable; they railed against WMC but were themselves the most parasitic of capitalists, they speechified against Western imperialism but allied themselves with the most nefarious of Northern business interests, they spoke of using the state to defend and advance the interests of the poor while looting SOE's, thus driving up the costs of basic services. Zuma though had latched on to an 'enemy' and all the contradictions could be explained away as part of their agenda.

\#WMC and \#EWC muddied the waters but they could not save Zuma in the end. The ANC simply adopted \#EWC as official policy and it was thus no longer an idea that he alone could present himself as the champion of. After Nasrec, Zuma and his supporters blamed \#WMC and Western imperialism for his faction being ousted. He pushed harder than ever for \#EWC in a bid to expose his rivals as being against it, enthusiastically advancing the idea that South Africa's imbalances in land ownership could only be solved through a constitutional amendment. However, an understanding dawned within the ANC that it was unlikely these hashtags were meant to be implemented, as understood by Zuma, even if his clique remained in power. As a sign that \#EWC was more slogan than imperative, the dominant legal opinion is that a constitutional amendment is unnecessary to fulfill the objectives of radical land reform. Additionally, many have pointed out that even existing land laws have not prevented the ANC government from thoroughly mishandling redistribution, with large swathes of redistributed farms lying fallow or mysteriously assigned to politically prominent beneficiaries. \#EWC was deployed not in a rational, evidence-based, economic sense. Its effective ingredient was a tone of racial one-upmanship, triumphalism and deliberate contentiousness which it introduced into mainstream ANC discourse. This was an obviously 'unMandela' way of approaching social change. As we have seen, Mbeki cringed as well. The real purpose behind \#EWC in Zuma's hands was 
not to unlock economic potential, or even redress past ownership imbalances and historical wrongs: \#EWC, like \#WMC, were hand grenades lobbed into the future, creating the conditions for social and political disorder from which Zuma, and if not him then someone in his mould, would be able to profit from (Tleane 2018).

The problem with Zuma's appropriation of \#WMC and EWC is that, as his star fades and indeed implodes, valid critiques of South Africa's economic structure might, in the short term, also lose their democratic potency. By this, I mean their aptness to be part of a rational and evidence-based contestation of ideas will diminish as the state capture narrative of what is wrong in South Africa gains dominance. The hypocrisy and contentiousness with which \#EWC was deployed by Zuma have hardened attitudes against a good faith search for necessary compromise solutions to the economic conditions in which populism thrives. South Africa is unlikely to survive yet another promise of wide-scale redistribution that ends up in rehashed trickledown economics.

But this is the lesser of South Africa's current problems. The bigger issue is that by Zuma's ANC embracing these ideals in a chauvinistic and overheated manner, many South Africans, beyond just the youth attracted to the EFF's rhetoric, have had a bite of the beguiling fruit of politics by denunciation, no matter how thin the proof is or the weight of countervailing evidence. ANC front-benchers have become used to race-baiting. Otherwise worldly black professionals have had their heads clouded with elaborate 'hidden hand' conspiracy theories against Zuma, the BRICS Bank and, more emotively, 'our people'. It does not help that white civil society has become emboldened and irate in response and is itself poking the bear of reconciliation with the stick of ridicule. We are not there yet. But it is hard not to recognise that \#WMC and \#EWC function as calls to identity at an emotional level, activating powerful instincts to nativism, scapegoating, pogrom and, no matter the ruin, war in a population under economic stress. If Twitter is anything to go by, after Zuma, the target of \#WMC has morphed into a remarkable attack against Indian South Africans. The Twitter feeds of many black thought leaders are routinely peppered with jibes against the race of people with whom they happen to disagree. In this, they join the league of many white conservatives still trading in racial identities in the public sphere. There are no real principles at play here. Just a mode of operation.

It bears repeating that South Africa is home to an entrenched economic 
elite which is disproportionately white. They are the beneficiaries, directly and indirectly, and to differing extents, of past injustices (Saul \& Bond 2014). Redistributive measures are necessary not only for economic development but also to mitigate the poverty that stalks the country. That the white community will, through law and policy, be disproportionately on the ceding side of economic opportunity is a fact of democratic and demographic politics. Concessions may even have to be wrought from them. However, the demand for expropriation as a panacea to, and white monopoly capital as a villain responsible for South Africa's ills, obscures something as important as it is unpalatable; the culpability of Black Nationalist politics and Zuma's ANC, which has squandered the opportunity for meaningful upliftment of thousands of black people over the last ten years. Even under \#WMC and with existing property relations intact, an enormous surplus of wealth has been provided to the ANC government by taxes and other receipts during Zuma's terms. Such is the pervasiveness of corruption and the monumental and callous waste under Zuma, one must question whether the dismantling of \#WMC and the arrival of \#EWC will give the poor much joy.

To thus add to the conundrums facing Ramaphosa, we have an unleashed racial chauvinism, easy scapegoating, hyperbolic accumulation of grievances and instant economic 'solutions' taking hold, dressed up as advancing the cause of the African poor and downtrodden, but in reality just new opportunities for corrupt deals and a quick accumulation of wealth.

Ramaphosa has tried to disown as nonsensical and disparaging of entrepreneurs, at least one hashtag, \#WMC. But, in pushing aside all the ideas that Zuma embraced, there is a likelihood that capital will avoid the chastening it deserves during President Ramaphosa's highly likely five-year term, such as the truly damaging aspects of price collusion, transfer pricing, profit-shifting, hiding of beneficial ownership, and the use of off-shore secrecy jurisdictions in some of its business dealings, as well as aggressive tax avoidance.

After all, this is a terrain that Ramaphosa himself stands accused of exploiting.

\section{The Dream Renewed?}

On Valentine's Day 2018, just before midnight, the Zuma presidency closed with his late-night resignation. In the face of an overwhelming vote of noconfidence in Parliament the next day, Zuma indignantly resigned. The 


\section{Ashwin Desai}

reversal of fortune was swift. For about a week, a mood of elation swept the country. Perhaps elation is the wrong word. It was more like the removal of shame, waking up from a bad dream to find one is not after all standing naked in the examination hall of nations.

It could so easily have been different but for the month of December 2017, when Zuma's chosen successor (and ex-wife Dr. Nkosazana DlaminiZuma) was defeated by a whisker (2,440 to 2,261 votes) in that now famous ANC poll at Nasrec.

These results gave an immediate sense of how divided the ANC is. Later revelations of the millions that Ramaphosa's campaign spent on wooing delegates to vote for him only reinforced this perception. Clearly, many ANC delegates did not vote on ideological grounds or due to some anti-corruption zealousness but rather on who could pay them more for their support. Despite Ramaphosa's victory in assuming the ANC presidency and winning the national elections in 2019, the factions within the ANC remain, as do those who were part of Zuma's criminal enterprise and those who have become used to trading their positions for all kinds of corrupt deals.

Italian philosopher Antonio Gramsci proposed the idea of a war of manoeuvre and a war of position to advance the notion of how state power is attained and consolidated. The war of manoeuvre is a direct frontal attack that lends itself to 'circumstances in which a decisive change in the balance of social and political power could be achieved at one stroke, so to speak' (Massey \& Rustin 2015: 204). The war of position is more akin to trench warfare in a conjuncture in 'which no sudden changes in the balance of power are feasible, but where nevertheless gains over the long-term can be made' (Massey \& Rustin 2015: 204).

It is the contention of this article that, given the nature of Ramaphosa's close victory in the race for the ANC presidency and the fact that many of the corrupt ANC deployed remain embedded in state structures, his actions will be largely limited to a war of position within the ANC, while the broader issues around a radical re-think of economic policy will be put on the back-burner.

The first months of the Ramaphosa presidency set the trend of a careful pushing back of the Zuma years. In a study of patient housekeeping, Ramaphosa began the process of trying to roll up the criminal enterprise that was Zuma's presidency, arresting the country's path to post-colonial ignominy. For this process, Ramaphosa is relying on adverse court judgments against former President Jacob Suma, and Zuma's keepers, in some of the cases, 
started years before, and fortuitously ripening in the months after Zuma's resignation.

The fact that Ramaphosa needs the gavel of an arm of state to justify dispatching obviously corrupt colleagues against whom serious allegations of fraud and maladministration lie - shows how weak his position is. For every Gupta stooge removed, two remain safely in place. Unfortunately, for the most part, for leaders in the ANC, particularly at municipal and provincial levels, 'payola' is not a matter of feathers. It is the nest itself. Many are career politicians or come from low-paying, low-skill jobs and, even with their normal salary, could never sustain a middle-class lifestyle. The entire ANC, not one faction, is more than anything a giant patronage machine and nothing is more unforgivable than not providing salaries and associated rent-seeking opportunities for all those who wield power in their little corner or constituency of ANC structures. Nothing illustrates the depth of the corruption rot than the Bosasa web of patronage unfolding at the Zondo Commission. There are huge barriers, some would say insurmountable, for Ramaphosa to excise corruption beyond the Guptas and Watsons, if even that far.

What does it say about the character of the ANC that it could keep Zuma for so long, 'becoming' as Fanon would have it, 'a willing tool in the hands of the leader' whose 'inner purpose was to become the general president of that company of profiteers impatient for their returns' $(2001: 139,148)$. Forget \#WMC. What about black monopoly governance and how this has worked out? In some respects, the answer flows from the hold that a leader playing the victim, playing up race and insinuating imperialist plots has over the national psyche. Because of our history, these tropes have an enduring material basis. Cloaking personal and chauvinist interests in high-sounding principle is a national sport in South Africa. It is hard to distinguish between those who fail because they are daft and those unfairly pulled down, those who are in need and those who envy the stuff of others, and those who agitate for necessary change or reckless ruin.

One truth is discerned in the criticism of Cyril Ramaphosa, South Africa's new president. Unlike Mandela, Mbeki or Zuma, Ramaphosa did not go into exile or join the liberation armies. Neither was he incarcerated on Robben Island. He only joined the ANC in the second half of the 1980s, spending his time building a trade union inside the country (Butler 2007: 224). After playing a central role at the Congress for a Democratic South Africa (CODESA), Ramaphosa famously entered business, becoming a billionaire as 
one of the preferred black partners of white companies seeking to establish their transformation credentials. For over a decade, he languished in the luxury of game farms, private jets and buffets that could feed a village. He infamously bought a single buffalo for R18 million and, as a shareholder in Lonmin platinum mine, motivated for striking workers to be confronted by the police as criminals. His intervention was subsequently ruled not to have been legally wrongful, but the fact is that in 2014, 34 mineworkers were gunned down at Marikana after the 'concomitant' police action he urged. He was also fingered for abetting both Lonmin in blatant Illicit Financial Flow (IFF) profit transfers to Bermuda, and MTN - the largest African cellphone firm - in its major profit outflows to Mauritius. His name also flashed in the 'Paradise Papers' leak in late 2017 as a tax haven culprit, through his key holding company, Shanduka coal (Bond 2019).

There are legitimate questions about whether Ramaphosa is committed to truly redistributive policies, particularly if they create an even more risky investor and debt servicing climate. Whereas Zuma was prone to flourishes over Western imperialist plots and use of the state to squeeze monopoly capital, Ramaphosa's instincts place more trust in the market; perhaps one could go so far as to say protection of the market and desire to please the rating agencies. In the meantime, leftist rhetoric sits uneasily on his well-cadenced tongue. If it were not for the need to garner votes from constituencies with a taste for melodramatic, messianic promises, one gets the sense he would abandon talk of advancing the national democratic revolution and other 'liberation speak' hangovers altogether. However, his biography does open him up to attacks of being a 'plant' in the movement and not fully grasping ANC traditions.

Witness ANC secretary-general Ace Magashule in the immediate aftermath of being exposed for meeting Jacob Zuma at a Durban Hotel: 'I am not a product of white people. I am not a product of capital. There are people who are the products of the white man in the ANC (The Mercury 2 October 2018).

There is no immediate Left impulse outside the Tripartite Alliance, opening up new radical political possibilities, pioneering new accumulation and redistribution paths. Leaders of the \#FeesMustFall movement have largely been siphoned into the ANC and EFF. The EFF is itself mired in its own corruption allegations and has a tendency to make politics out of racial baiting despite its avowed Marxism-Leninism-Fanonism. The Socialist Revolutionary Workers Party (SRWP), sponsored by the National Union of Metalworkers 
(NUMSA), was nowhere near ready to make an impact in the 2019 elections or in the broader body politic, its language that of an ossified Marxism out of the Stalinist school. As it turns it failed to get a single seat in parliament. NUMSA meanwhile is pre-occupied with defensive battles to save jobs in the sector it organises, especially within SOE's, marching to places like Denel, the arms manufacturer to prevent lay-offs and demand we keep producing weapons of war. Its approach to the country wide mobilisation against corruption was to baulk at what they saw as being suckered into a middle-class campaign, adopting 'the capitalist system is corrupt, socialism is the answer' militant abstentionism (Ashman et al. 2017). The problems associated with a political party sponsored and dominated by a single union is as least as old as Lenin. The NUMSA sponsored South African Federation of Trade Unions (SAFTU) is also caught up in its own revolutionary tailism. When the notorious Zuma backer and former Free State feudal lord, Ace Magashule announced that ANC policy was to nationalise the Reserve Bank, SAFTU was quick to support him. It is the self-same SAFTU that sees the ANC as mired in corruption and pointed in a direction of neo-liberalism whose course they argue it is determined not to change. Despite this, it wants the Reserve Bank to fall under the control of the very same ANC (SAFTU 2019). This episode raises the issue of how the Left cannot contemplate opening a debate beyond a reflexive commitment to nationalisation as the only way to effect distribution of resources. This, despite the fact that nationalisation has shown, as in the case of Angola as James Ferguson (2015) points out, as benefitting a small elite, reminiscent of our own BEE.

These challenges on how to distribute wealth in ways that move beyond feeding into the ANC's corrupt patronage machine are more pertinent than ever, given that there will be little progress in creating decent jobs in the short to long term, while poverty becomes more pervasive and inequality deepens (Bundy 2016).

A related issue is the whole notion of a 'pure' revolutionary subject. I was nudged into reflecting on this by a few arresting lines in an article by Ashman et al.:

By late 2015 it had become clear that some NUMSA-funded initiatives in which Vavi [the former general-secretary of COSATU and lynch-pin of SAFTU-AD] was involved were taking the form of popular fronts that privileged middle-class voices at the expense of 
the workers. NUMSA's corrective pullback was sharp and has seen Vavi concentrating on building the new federation rather than the middle-class-led anti-corruption Zuma Must Fall and Save South Africa Campaigns (2017: 97).

Is corruption that involves the looting of state resources not worthy of intervention? Are not the working class affected by the rising cost of basic services linked to this looting? Are not the middle classes, especially the new black middle class, mired in debt and angry that the escalator up the class hierarchy has stalled, if not catapulting them downwards and therefore becoming potential allies? Is the working class leadership not capable of entering this domain and fighting for hegemony? In truth, what animates some parts of the South African Left is that the working class will arise phoenix-like from their 'apathy', to steal Oupa Lehulere's (2017: 11) words, march out the factories and mines, seize the Union Buildings, raise the red flag of the hammer and sickle and inaugurate the dictatorship of the proletariat. The attraction to Gramsci's war of manoeuvre, born out of an obsession with a particular reading of the Bolshevik Revolution, is a persistent theme of the Left outside the ANC Alliance. It often allows them to shun battles that seek to protect constitutionalism and the rule of law, holding out for that single moment when, in scenes reminiscent of Birnam Wood marching on Macbeth, the working class will achieve a 'decisive change in the balance of social and political power ... at one stroke' (Massey \& Rustin 2015: 204).

Left thinkers from Marx to Fanon are prone to argue that without a revolutionary ideology, resistance is bound to flounder and be dissipated. One of the ironies of the South African landscape is that those rebellions that suddenly spring up in what is termed service delivery protests, or more optimistically, insurgent citizenship (Brown 2015), or single-issue mobilisations like \#FeesMustFall, despite lacking any overarching ideology, have often made a huge impact on the body politic but then tend to fall away, often being regularised into the workings of the ANC (Veriava 2019). On the other hand, organisations that espouse a tight ideological frame of reference like the EFF, SACP or Black First Land First (BLF) are often guilty of acting in ways that make a mockery of their avowed ideological prescripts. So, the ultra-radical, militant Fanonian outfit BLF hung on to the coat-tails of the Zuptas. Likewise, the Marxist-Leninist SACP, those keepers of the nationaldemocratic road to socialism are supporters of billionaire Cyril Ramaphosa. 
If there is to be a more determined commitment to redistribution in the immediate, then it will be sparked from strands inside the ANC that are pushing for Radical Economic Transformation (RET). The problem for those within the ANC who desire this for all the right reasons, is that Zuma and his lieutenants from the state capture sorties want to own this impulse. As Ramalaine and Niehaus point out, 'Zuma, in his post-presidential life continues to seek to define this $[R E T]$ as his real legacy and reading the trajectory of the ANC leadership know that there is a vacuum. From the bedrock of that awareness he has decided to stay in touch in the daily politics and discourse...' (The Mercury 9 January 2019).

Ramaphosa, while keeping Zuma on-side, sought in his $12^{\text {th }}$ January 2019 statement marking the ANC's $107^{\text {th }}$ anniversary, to mitigate the import of RET rather than pushing it back, emphasising the creation of a conducive investment climate, economic viability and productivity. Those wishing to sustain the RET narrative inside the ANC will find it hard-going. One of the problems is that they have not found a champion to coalesce around beyond Zuma. Many of Zuma's erstwhile supporters have taken the option of founding new parties, thus fracturing a bloc that could unite around RET inside the ANC. The SACP and Cosatu have thrown their lot in with Ramaphosa, strengthening his ability to push back against RET. Ramaphosa's 2019 national election victory has allowed him to be consolidate his dominance in the ANC but not have hegemony to steal a phrase from Ranajit Guha's (1997) reworking of Gramsci. This means he has to constantly try and push back against the still influential remnants of Zuma's people who seek to undermine him by fighting rear-guard battles inside the party.

In Njabulo Ndebele's The Cry of Winnie Mandela (2003: 71), the character Marara Joyce Baloyi wonders: 'Have dislocation and contradiction become part of the structures and feeling that may define our character? A nation of extremes!' Which way will the balance ultimately go between creativity and destruction?

The pendulum that swung towards destruction under Zuma shows signs of being pulled back. For all the weighty issues that mark the conjuncture, there is an upside that emanates from Zuma's removal. Ramaphosa's war of position has meant that the looting of the state has been stymied, albeit not eliminated. Corrupt politicians and business people are looking over their shoulders. Good people in the public service have rallied and are asking questions, running interference, standing up, testifying. The NPA and SARS 
have some capacity restored. Civil society is once more the flavour. Ethical questions are once more heard in the corridors of power.

While Ramaphosa's war of position holds no purse for fundamental transformation, it does create spaces in which new ways of organising and new forms of political action can emerge. What is clear is that Ramaphosa's holding pattern will push back the proponents of state capture but does not signal a deeper and more fundamental shift, especially at the level of the economy.

Whether this space is grabbed by racial authoritarian populists or a centre-left that looks both ways at once - attracting foreign direct investment while hoping to implement a progressive redistributive economic programme is what the terms of battle will be about.

\section{References}

Areff, A. 2015. Rich White Men made Mandela Turn against the Revolution Malema. News24, 26 November. Available at:

http://www.news24.com/SouthAfrica/News/rich-white-men-mademandela-turn-against-the-revolution-malema-20151126

(Accessed on 28 September 2016.)

Ashman, S., Z. Levinson \& T. Ngwane. 2017. South Africa's ANC: The Beginning of the End? Catalyst 1,2: 71 - 106.

Barchiesi, F. 2011. Precarious Liberation: Workers, the State, and Contested

Social Citizenship in Postapartheid South Africa. Albany: State University of New York Press.

Basson, A. 2012. Zuma Exposed. Johannesburg: Jonathan Ball.

Basson, A. \& P. du Toit. 2017. Enemy of the People: How Jacob Zuma Stole

South Africa and How the People Fought Back. Johannesburg: Jonathan Ball Publishers.

Bhorat, H., M. Buthelezi, I. Chipkin, S. Duma, L. Mondi, C. Peter, M. Qobo et al. 2017. Betrayal of the Promise: How South Africa is Being Stolen. Stellenbosch: State Capacity Research Project (Convenor Mark Swilling). Black, A., S. Craig \& P. Dunne. 2016. Capital Intensity, Industrial Policy and Employment in the Manufacturing Sector. REDI3x3 Working Paper 23: 1-30. Available at:

http://www.redi3x3.org/sites/default/files/Black\%20et\%20al\%202016\% 20REDI3x3\%20Working\%20Paper\%2023\%20Capital\%20intensity\%20 and $\% 20$ employment $\% 20$ FINAL_0.pdf 
(Accessed on 20 December 2018.)

Bond, P. 2014. Elite Transition. London: Pluto Press.

Bond, P. 2017. In South Africa, Ramaphosa Rises as Lonmin Expires Workers, Women and Communities Prepare to Fight, not Mourn. CounterPunch December 20. Available at:

https://www.counterpunch.org/2017/12/20/in-south-africa-ramaphosarises-as-lonmin-expires-workers-women-and-communities-prepare-tofight-not-mourn/

(Accessed on 21 December 2017.)

Bond, P. 2019. South Africa suffers Capitalist Crisis Déjà vu. Monthly Review January 1. Available at:

https://monthlyreview.org/2019/01/01/south-africa-suffers-capitalistcrisis-deja-vu/

(Accessed on 16 January 2019.)

Brown, J. 2015. South Africa's Insurgent Citizens: On Dissent and the Possibilities of Politics. London: Zed Books.

Bundy, C. 2014. Short-Changed? South Africa since Apartheid. Johannesburg: Jacana.

Bundy, C. 2016. Poverty in South Africa: Past and Present. Johannesburg: Jacana.

Butler, A. 2007. Cyril Ramaphosa. Johannesburg: Jacana.

Calland, R. 2013. The Zuma Years. South Africa's Changing Face of Power. Cape Town: Zebra Press.

Chipkin, I. 2016. The Decline of African Nationalism and the State of South Africa. Journal of Southern African Studies, 42,2: 215 - 227.

Desai, A. 2002. We are the Poors: Community Struggles in Post-Apartheid South Africa. New York: Monthly Review Press.

Fanon, F. 2001. The Wretched of the Earth. London: Penguin.

Ferguson, J. 2015. Give A Man A Fish: Reflections on the New Politics of Distribution. Durham and London: Duke University Press.

Gevisser, M. 2007. Thabo Mbeki: The Dream Deferred. Johannesburg: Jonathan Ball.

Guha, R. 1997. Dominance and Hegemony: History and Politics in Colonial India. Cambridge. Cambridge University Press.

Gumede, W. 2007. Thabo Mbeki and the Battle for the Soul of the ANC. Cape Town: Zebra Press.

Jacobs, S. 1999. An Imperial Presidency? Siyaya 6, Summer: 4 - 9. 
Johnson, R.W. 2010. South Africa's Brave New World: The Beloved Country Since the End of Apartheid. London: Penguin Books.

Kasrils, R. 2017. A Simple Man: Kasrils and the Zuma Enigma. Johannesburg: Jacana.

Khumalo, F. 2016. \#Zuptasmustfall and other Rants. Johannesburg: Penguin Random House.

Laclau, E. 2005. On Populist Reason. London: Verso.

Lehulere, O. 2017. The Corruption of a Dream 2017. Khanya Journal 36, Special edition, April/May: 1 - 11.

Lodge, T. 2003. Politics in South Africa: From Mandela to Mbeki. Indiana: Indiana University Press.

MacDonald, M. 2004. The Political Economy of Identity Politics. The South Atlantic Quarterly 103,4: 629 - 656.

Malala, J. 2015. We Have now Begun our Descent. Johannesburg: Jonathan Ball Publishers.

Malikane, C. 2017. Concerning the Current Situation. Khanya Journal 36, April/ May. Available at: http://khanyajournal.org.za/concerning-thecurrent-situation-christopher-malikane-07-april-2017/

(Accessed on 20 December 2018).

Marais, H. 2011. South Africa Pushed to the Limit: The Political Economy of Change. London and Cape Town: Zed Books and UCT Press.

Massey, D. \& M. Rustin. 2015. Displacing neoliberalism. In Hall, S., Massey,

D \& M. Rustin (eds.). After Neoliberalism: The Kilburn Manifesto. London: Lawrence and Wishart.

Mbali, M. 2013. South African AIDS Activism and Global Health Politics. London: Palgrave Macmillan.

Mbeki, T. 2018. What Then about Land Expropriation without Compensation? The National Democratic Revolution Must Resolve the Intimately InterConnected Land and National Questions! Available at:

https://www.mbeki.org/2018/09/25/the-unresolved-national-questionthe-ndr-and-the-land-question/ (Accessed on 1 October 2018).

McKenzie, G. 2017. Kill Zuma by any Means Necessary. Johannesburg: ZAR Empire.

Mkokeli. S. 2016. Fraud: SA's Treasury on the Prowl. Business Report October 6. Available at:

https://www.iol.co.za/business-report/economy/fraud-sas-treasury-onthe-prowl-2076829 (Accessed on 10 September 2018). 
Morton, A. 2007. Unravelling Gramsci: Hegemony and Passive Revolution in the Global Economy. London: Pluto Press.

Motau, T. 2018. vbs Mutual Bank: The Great Bank Heist. Investigator's Report to the Prudential Authority. Available at:

https://www.banking.org.za/docs/default-source/publication/reports/vbsmutual-bank---the-great-bank-heist.pdf?sfvrsn=2

(Accessed on 6 January 2019.)

Ndebele, N. 2003. The Cry of Winnie Mandela. Cape Town: David Philip.

Pauw, J. 2017. The President's Keepers: Those Keeping Zuma in Power and Out of Prison. Cape Town: Tafelberg.

Public Protector 2016. State of Capture. Report No: 6 of 2016/17. Pretoria: Public Protector South Africa.

Ramalaine, C. \& C. Niehaus. 2019. An Elitist ANC Leadership finds Pro-poor Agenda a Discomfort. The Mercury 9 January. Available at:

https://www.iol.co.za/pretoria-news/an-elitist-anc-leadership-finds-propoor-agenda-a-discomfort-18751296

(Accessed on 10 January 2019.)

Russell, A. 2011. After Mandela: The Battle for the Soul of South Africa. Johannesburg: Random House.

Saul, J. \& P. Bond. 2014. South Africa - The Present as History: From Mrs Ples to Mandela and Marikana. Johannesburg: Jacana.

Smith, N. 2018. The South African Left in the Time of Ramaphosa. Catalyst 2: $146-163$.

South African Federation of Trade Unions. 2019. Nationalise the Reserve Bank. January 17. Available at:

http://saftu.org.za/nationalise-the-reserve-bank-saftu/

(Accessed on 20 January 2019).

Southall, R. 2017. White Monopoly Capital: Good Politics, Bad Sociology, Worse Economics. The Conversation, May 11. Available at:

http://theconversation.com/white-monopoly-capital-good-politics-badsociology-worse-economics. (Accessed on 6 June 2017).

Thamm, M. 2017. The Art of Spin 2.0: Bell Pottinger Apology - Playing the Victim - Not Accepted. Daily Maverick July 6. Available at:

https://www.dailymaverick.co.za/article/2017-07-06-the-art-of-spin-2.0bell-pottinger-apology-playing-the-victim-notaccepted/\#.WYcDc2wUmUk

(Accessed on 25 July 2017.) 
Tleane, L. 2018. South Africa's Radical Economic Transformation. Monthly Review September 1. Available at:

https://monthlyreview.org/2018/09/01/south-africas-radical-economictransformation/

(Accessed on 8 September 2018.)

Veriava, A. 2019. Leaving Solomon: A(n) Impressionistic Portrait of the FMF Movement at Wits. The South Atlantic Quarterly 118,1: 195 - 204.

Waldmeir, P. 1997. Anatomy of a Miracle: The End of Apartheid and the Birth of a New South Africa. London: Viking.

Ashwin Desai

Department of Sociology University of Johannesburg Kingsway Campus Johannesburg ashdesai1@gmail.com 